\title{
RA?EGA
}

O ESPACYO GEOGRÁFICO EM ANÁLISE

\section{VULNERABILIDADE SOCIOAMBIENTAL NA ÁREA DE OCUPAÇÃO CONTÍNUA DO LITORAL DO PARANÁ - BRASIL}

\section{ENVIRONMENTAL VULNERABILITY IN THE AREA OF CONTINUOUS OCCUPANCY OF COASTLINE PARANÁ - BRAZIL}

\author{
Claudio Jesus de Oliveira Esteves \\ Instituto Paranaense de Desenvolvimento Econômico e Social \\ Curitiba, $P R$ \\ e-mail: claudiaojoe@ig.com.br
}

\section{Recebido em: 23/12/2014}

Aceito em: 02/09/2015

No litoral do Paraná configurou-se uma ocupação contínua que envolve quatro municípios: Paranaguá, Matinhos, Pontal do Paraná e Guaratuba. Neste contexto, nos últimos 30 anos, gradualmente foram ocupadas as áreas do Tabuleiro I e II e da Vila Nova (Matinhos), recorte espacial da pesquisa empírica demonstrada neste artigo, onde não ocorreu à instalação de redes de coleta de esgoto resultando, conjuntamente com outros fatores, em degradação ambiental. Também houve a ocupação em áreas de risco ambiental associado às inundações urbanas. Neste trabalho a interação espacial entre o risco e a degradação ambiental é entendida como a dimensão da vulnerabilidade ambiental. Foi traçado como objetivo central analisar a dinâmica populacional e urbana dos Municípios Balneários da Área de Ocupação Contínua do Litoral do Paraná, relacionando a ocupação do Tabuleiro I, Tabuleiro II e da Vila Nova e identificar nestas três localidades situações de vulnerabilidade socioambiental. A análise teórica partiu dos pressupostos da geografia socioambiental. A cidade de Matinhos foi concebida enquanto ambiente urbano do qual derivou um sistema ambiental urbano no qual o Tabuleiro I e II e a Vila Nova foram considerados como parte integrante e integrada. Os dados sobre a frequência de inundações e da cobertura da coleta de esgoto permitiram criar áreas para diferentes categorias de vulnerabilidade ambiental. Os dados socioeconômicos e de habitação avaliados sobre estas áreas comprovaram situações de alta vulnerabilidade socioambiental.

Palavras-chave: inundações, risco, degradação, sistema ambiental urbano.

\section{Abstract}

On Paraná coast, there has been set up an occupation that involves continuous of four counties: Paranaguá, Matinhos, Pontal do Paraná and Guaratuba. In this 


\section{VULNERABILIDADE SOCIOAMBIENTAL NA ÁREA DE OCUPAÇÃO CONTÍNUA DO LITORAL DO PARANÁ - BRASIL}

context, the past 30 years, gradually were occupied areas of the board I and II and the Vila Nova (Matinhos), spatial area of empirical research demonstrated in this article, where there has been the installation of sewage collection networks resulting in conjunction with other factors in environmental degradation. There was also the occupation of risky areas associated with urban flooding. In this paper spatial interaction between risk and environmental degradation is understood as the dimension of environmental vulnerability. The central objective was to analyze the population and urban dynamics of Beach Resorts of Continuous Occupation Area of Paraná Coast, relating to Tabuleiro I, Tabuleiro II and Vila Nova occupation and identify these three localities environmental situations of vulnerability. The theoretical analysis of the assumptions set out of the environmental geography. The Matinhos city was conceived as an urban environment which an urban environment system derived in which the Tabuleiro I and II and Vila Nova were considered as an integral and integrated. The data about the frequency of flooding and sewage coverage have created areas for different environmental vulnerability categories. The socioeconomic and housing data evaluated on these areas have proven environmental situations of high vulnerability.

Keywords: flooding, risk, degradation, urban environmental system.

\section{INTRODUÇÃO}

No litoral brasileiro se identificam espaços com diferentes adensamentos urbanos e populacionais, nos quais se distinguem múltiplos tipos de usos. Resguardadas as devidas escalas apresentam-se no Paraná atributos característicos das demais porções urbanas do espaço litorâneo brasileiro. No litoral paranaense configurou-se uma ocupação contínua que envolve áreas urbanas de quatro municípios: Paranaguá, Matinhos, Pontal do Paraná ${ }^{\text {e }}$ Guaratuba. O primeiro se vincula a uma funcionalidade estruturada em torno do Porto Dom Pedro II, um dos maiores do Brasil, e os demais municípios se caracterizam por um padrão relacionado às atividades turístico-balneárias. Nesses últimos, simultaneamente a apropriação dos espaços paralelos à orla marítima por segundas residências, ocorreu outra ocupação, nas áreas opostas ao mar, destinadas ao morador permanente, boa parte dos quais imigrantes.

Nas cidades litorâneas acumulam-se problemas socioambientais de diversas ordens, concorrendo para a materialização de situações de degradação e risco

\footnotetext{
${ }^{1}$ O município de Pontal do Paraná paulatinamente está se inserindo na dinâmica industrial e portuária.
} 


\section{ESTEVES, C. J. O. \\ VULNERABILIDADE SOCIOAMBIENTAL NA ÁREA DE OCUPAÇÃO CONTÍNUA DO LITORAL DO PARANÁ - BRASIL}

ambiental. Os locais que apresentam estas condições, especialmente aqueles habitados por populações carentes, caracterizam áreas de alta vulnerabilidade socioambiental, situação que se agudiza onde as infraestruturas e os serviços de saneamento ambiental são deficitários.

Nas áreas urbanas os riscos ambientais abarcam uma gama de possibilidades de acontecimentos desastrosos de diferentes escalas. Nos últimos anos alguns eventos que ocorreram na faixa litorânea, chamaram a atenção pela magnitude e a trágica dimensão das perdas de vidas humanas e dos prejuízos materiais como o episódio ocorrido em abril de 2010 que atingiu o Estado do Rio de Janeiro². Em março de 2011 as inundações e deslizamentos nos municípios de Antonina, Morretes, Guaratuba e Paranaguá resultaram em três mortes, cerca de 250 feridos, mais de 2000 desabrigados, centenas de casas destruídas, além de destruições e avarias em pontes, estradas e prejuízos agrícolas ${ }^{3}$.

Geralmente a mídia dá amplo destaque aos eventos danosos de grande magnitude. Contudo, os desastres considerados de menor intensidade, nem sempre tão repercutidos, também acarretam em danos, não raro óbitos. É o caso da maioria das ocorrências na Área de Ocupação Contínua do Litoral do Paraná, particularmente em Matinhos, município com registro recorrente de inundações urbanas e um histórico de prejuízos materiais, desabrigados e óbitos, especialmente pelo contágio por leptospirose pós-inundação (ESTEVES, 2011, p. 183).

O estudo relatado neste texto enfoca a problemática ambiental urbana na Área de Ocupação Contínua do Litoral do Paraná pelo viés da vulnerabilidade socioambiental. $\mathrm{O}$ ambiente urbano é representado sob a perspectiva de um sistema ambiental urbano - SAU. A pesquisa empírica foi realizada no Tabuleiro I e II e na Vila Nova, município de Matinhos-PR (FIGURA 1), que em conformidade com a metodologia é representada em um SAU denominado como Sistema Ambiental Urbano de Matinhos/Tabuleiro I e II e Vila Nova (SAUMTVN).

\footnotetext{
${ }^{2}$ Nessa ocasião a problemática socioambiental ficou evidenciada no deslizamento que atingiu o Morro do Bumba, em Niterói, quando cerca de 50 casas, construídas sobre o aterro de um antigo "lixão", ficaram soterradas e houve dezenas de óbitos. A região serrana do Rio de Janeiro, fruto da relação entre chuvas intensas e ocupação desordenada em encostas, contabilizou 912 vítimas fatais.

${ }^{3}$ Em junho de 2014 no Paraná 144 municípios decretaram situação de emergência e três estado de calamidade pública em decorrência das fortes chuvas. Nesta ocasião foram registrados 12 óbitos.
} 


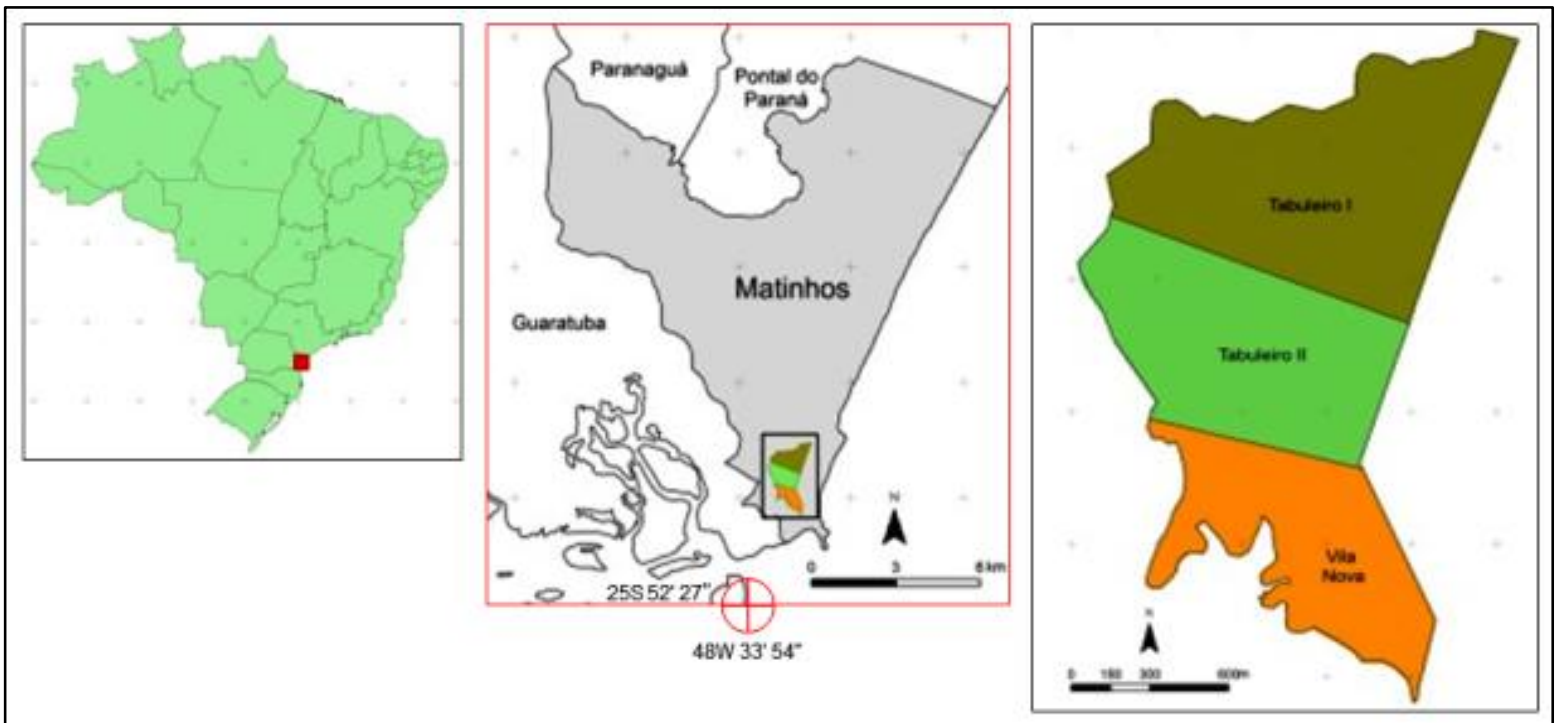

Figura 1: Localização do Tabuleiro I e Il e da Vila Nova - Matinhos - Paraná.

As localidades delimitadas no SAUMTVN receberam expressivo contingente de imigrantes nos últimos 30 anos (ESTEVES, 2011, p. 129 a 147). A ocupação destas áreas não foi acompanhada da instalação da rede pública de coleta de esgotos e avançou sobre áreas naturalmente inundáveis que, somadas as intervenções advindas da urbanização e as alterações na rede hidrográfica superficial, resultaram em áreas de risco ambiental associadas às inundações urbanas. Os resultados, segundo os critérios adotados nos procedimentos metodológicos, apontaram que a maior parte das áreas representadas no SAUMTVN é de Média-Alta e/ou Alta Vulnerabilidade Ambiental. Verificou-se ainda que os dados ambientais, sociais e econômicos levantados nestas áreas caracterizam situações de alta vulnerabilidade socioambiental.

No texto, após esta introdução, são expostos a proposta e os procedimentos metodológicos. Na sequência o foco recai sobre dinâmicas urbanas e naturais do universo sistêmico no qual está inserido o SAUMTVN, especialmente a Área de Ocupação Contínua do Litoral do Paraná, e as correlações com a problemática ambiental, discussão que contextualiza os itens subsequentes, dedicados a caracterizar as situações de risco, degradação e vulnerabilidade ambiental que são os elementos indispensáveis para a análise da vulnerabilidade socioambiental no SAUMTVN. 


\section{PROPOSTA METODOLÓGICA}

A proposta metodológica filia-se ao campo da geografia socioambiental, cujo princípio se baseia na interação da sociedade enquanto sujeito ativo nas dinâmicas referentes às questões ambientais contemporâneas (MENDONÇA, 2002, p. 126). Entre as abordagens que buscam compreender a cidade sob a ótica das relações entre sociedade e natureza destacam-se aquelas que a tomam sob a concepção de ambiente urbano, a exemplo da preposição de Mendonça (2004, p. 185 a 207) intitulada Sistema Ambiental Urbano (SAU) adotada como modelo interpretativo para o presente estudo. Ao interpretar a cidade como um SAU admite-se a existência de todo um complexo fluxo de matéria e energia, de gênese natural e/ou originado da ação societária, que interage continuamente no ambiente urbano. Esses fluxos dinamizam as formas como se apresentam os elementos da natureza e da sociedade na cidade, configurando a materialidade urbana. No contexto urbano a dinâmica dos processos naturais é induzida pela dinâmica dos processos sociais e a ocorrência de problemas ambientais é fruto dessa complexa interação.

O Tabuleiro I e II e a Vila Nova, pela condição de bairros de Matinhos mantêm múltiplas interações com o ambiente representado. Essas relações são abordadas sob a perspectiva sistêmica, neste caso pelo doravante denominado Sistema Ambiental Urbano de Matinhos/Tabuleiro I e II e Vila Nova (SAUMTVN) que foi concebido como um sistema complexo e aberto. As localidades do Tabuleiro I e II e a Vila Nova pertencem e se integram, mediante fluxos e trocas de energias e matérias, as demais áreas representadas na figura 2 que formam o universo do sistema (Matinhos, Área de Ocupação Contínua do Litoral do PR, Paraná, Brasil, Oceano Atlântico, Terra, Universo...). 


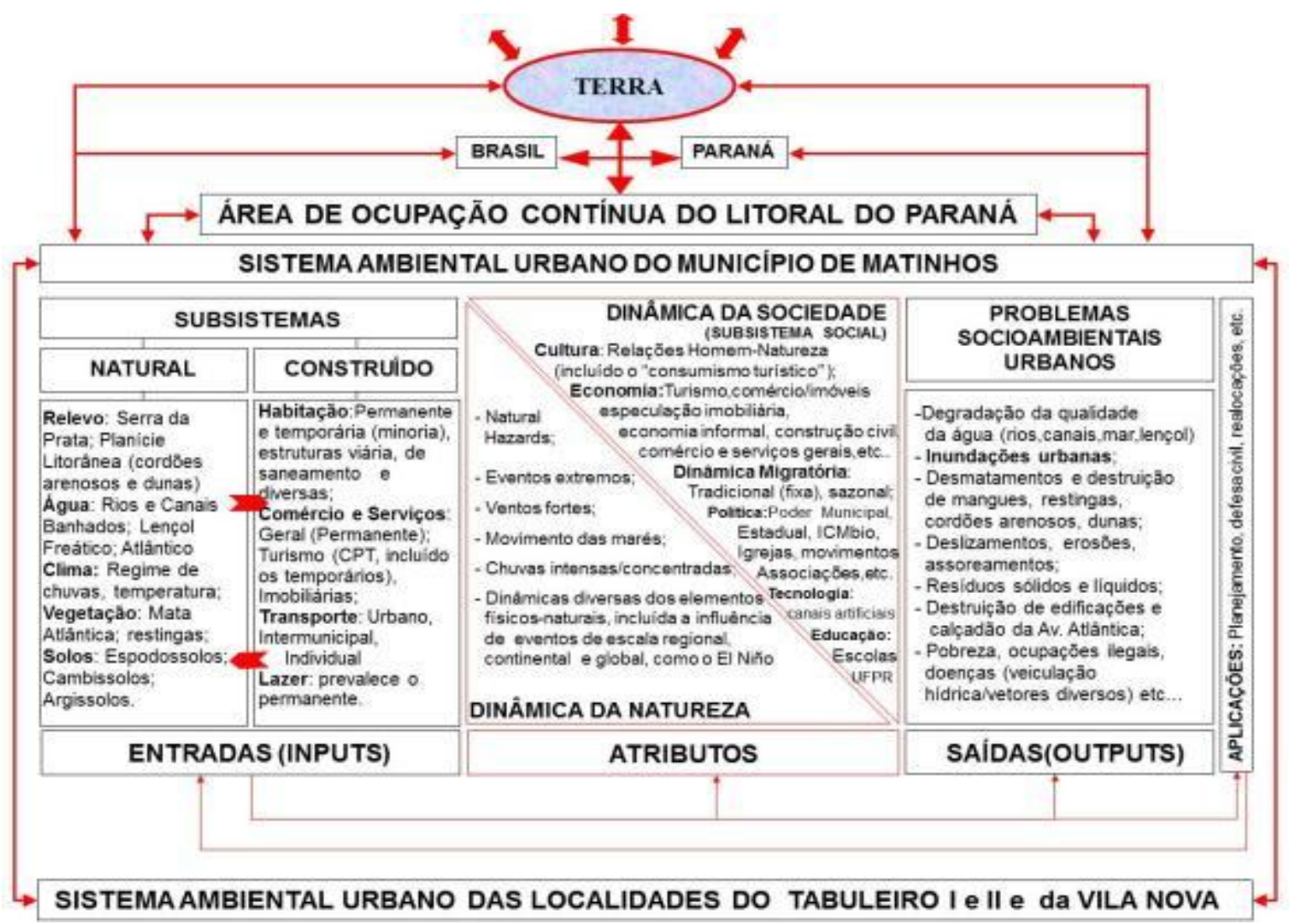

Figura 2 - Representação do SAUMTVN.

Organização: Cláudio Jesus de Oliveira Esteves (2011) - Adaptado de Mendonça (2004, p. 201).

A seguir, levando em consideração a proposição original (MENDONÇA, 2004, p. 185 a 207) e a estrutura do sistema é apresentada a composição do SAUMTVN (figura 2):

1. Entradas (Inputs): são os fluxos de energia de ordem natural e aqueles originários de processos sociais. Para a área estudada compreende:

Subsistema Natureza: refere-se aos componentes do meio físico-natural, especialmente o clima; à hidrografia (localmente alterada), o relevo; a vegetação e o solo. No universo sistêmico, destaca-se o Oceano Atlântico e a sua relação com os demais componentes do subsistema;

Subsistema Construído: refere-se às habitações e infraestrutura de serviços destinados a atender tanto à população permanente como à flutuante, incluído as estruturas de saneamento relativas aos serviços de água tratada e de esgoto. 


\section{ESTEVES, C. J. O. \\ VULNERABILIDADE SOCIOAMBIENTAL NA ÁREA DE OCUPAÇÃO CONTÍNUA DO LITORAL DO PARANÁ - BRASIL}

2. Atributos: é o Subsistema Social no sentido das instâncias sociais que dinamizam o SAU e as dinâmicas naturais, abrangendo os eventos extremos e episódicos. Os principais elementos dinamizadores são:

Dinâmica da natureza: refere-se às dinâmicas climáticas, particularmente ligadas aos regimes de chuvas, e das marés, incluindo, em ambas, as influências locais, regionais e globais. Os episódios mais abruptos, para o caso das chuvas, geralmente são registrados durante os meses mais quentes (verão). Inclui também as dinâmicas geomorfológica, pedológica, geológica e as demais etapas do ciclo hidrológico. Importante elemento dinamizador do SAUMTVN é o mar, seja pelo movimento das marés ou pela influência que exerce no clima.

Dinâmica da Sociedade: diz respeito ao papel das estruturas econômicas, políticas, sociais e culturais e a sua relação com o ambiente. É importante a influência da atividade turística, pois se associa à dinamização da economia, a ocupação do espaço, a atração de contingentes populacionais permanentes e temporários e a disseminação da cultura de consumo associada ao turismo. Também se associa a atuação dos agentes políticos e da especulação imobiliária. As ações das instituições públicas se relacionam a política, cujo principal componente é a prefeitura.

O atributo referente à dimensão social da produção do espaço é analisado sob a ótica do desenvolvimento histórico local/regional. Entende-se que ocupação recente, tanto a destinada para o veraneio como a destinada aos moradores permanentes, é produto do sistema econômico vigente que influencia na formação e configuração dos diferentes espaços, especialmente nas áreas que são regidas por condutas especulativas. Evidentemente que uma análise centrada somente na dimensão econômica é reducionista diante da complexidade envolvida em estudos que adotam o enfoque socioambiental. É fundamental compreender a forma como ocorrem às relações do homem com a natureza no atual estágio da sociedade capitalista, pois essas relações se reproduzem nas escalas locais. Entende-se que a organização econômica e social, relacionada ao pensamento filosófico, científico e cultural dominante em cada época é fundamental para essa compreensão (ENGELS, 1984, p. 469). Esse tratamento, embora distinto do método interpretativo da abordagem sistêmica, reconhece que não obstante sociedade e natureza serem 
parcelas do mesmo ambiente com fortes conexões entre si, em última instância cada qual possui dinâmica e métodos próprios de análise (LEFF, 2002, p. 49). Ao optar por esse procedimento interpretativo, devem-se trabalhar as perspectivas analíticas de forma dialética para não desvirtuar a proposta da abordagem socioambiental que é estudar as interações sociedade/natureza de forma integrada (MENDONÇA, 2002, p. 140).

3. Saídas do SAU: se referem aos problemas socioambientais urbanos, resultantes das interrelações entre os diversos subsistemas do SAUMTVN:

Degradação e poluição ambiental: fica evidente, por exemplo, na perda da qualidade da água das praias, rios e canais devido à contaminação e poluição;

Inundações: favorecida pela conjunção de fortes chuvas com maré cheia aliada aos impactos advindos da urbanização e intervenções na rede de drenagem.

Ocupações irregulares, favelamento: presente em várias áreas do SAUMTVN e no seu universo;

Fome, pobreza, doenças transmissíveis: fruto das desigualdades econômicas e sociais. Em relação às doenças agudizam-se após as inundações e pelas debilidades no sistema de coleta e tratamento de esgotos.

As condições de vulnerabilidade socioambiental se relacionam diretamente com as saídas do SAUMTVN. O caminho percorrido convergiu para identificar e analisar as saídas do SAU, que caracterizam as situações de vulnerabilidade socioambiental.

\subsection{Procedimentos Metodológicos Básicos}

O estudo referente à vulnerabilidade socioambiental foi feito a partir de adaptação da proposta de Alves (2006, p. 43 a 59) que a tipificou em São Paulo pela sobreposição espacial entre grupos populacionais pobres e de alta privação (vulnerabilidade social) com áreas de risco e/ou degradação ambiental (vulnerabilidade ambiental). Para caracterizar a vulnerabilidade socioambiental no SAUMTVN delimitaram-se as áreas de vulnerabilidade ambiental e nestas porções buscou-se demonstrar condições de vulnerabilidade social. As informações foram levantadas por meio da aplicação de um questionário em 280 domicílios distribuídos por todas as quadras, vielas e becos da região e entrevistas qualitativas com 
moradores e lideranças locais (ESTEVES, 2011, p.42 a 50). O roteiro do questionário e das entrevistas convergiu para os elementos definidores da vulnerabilidade: exposição ao risco, incapacidade de reação e a dificuldade de adaptação diante da consumação do risco.

O mapeamento das áreas de risco ambiental ocorreu a partir dos dados referentes à quantidade de alagamentos ocorridos no domicílio, por conta das inundações, definindo três áreas de risco: baixo risco, onde nunca havia ocorrido inundação; médio risco, locais com uma ou duas ocorrências de inundações; alto risco, locais onde já haviam ocorrido três ou mais inundações. As áreas de degradação ambiental foram associadas à disponibilidade da rede coletora de esgotos. As áreas que dispunham desse serviço foram consideradas como de baixa degradação e as localidades que não possuíam como de alta degradação. Pela sobreposição espacial dessas duas variáveis foram criadas as categorias de vulnerabilidade ambiental:

- Baixa Vulnerabilidade Ambiental: áreas de baixo/médio risco com cobertura da rede de esgotos;

- Média Vulnerabilidade Ambiental: áreas de alto risco com cobertura da rede de esgotos;

- Média/Alta Vulnerabilidade Ambiental: áreas de baixo/médio risco sem cobertura da rede de esgotos;

- Alta Vulnerabilidade Ambiental: áreas de alto risco sem cobertura da rede de esgotos.

Nos levantamentos na área de estudo constatou-se características que denotam condições de alta vulnerabilidade social ao comparar com dados do trabalho de Alves (2006; ESTEVES, 2011, pgs. 49 e 231). Para caracterizar a vulnerabilidade socioambiental no SAUMTVN foi feita uma análise sobre acesso à rede pública de esgoto e água tratada, renda e composição etária familiar nas áreas de vulnerabilidade ambiental. Também foram analisadas outras informações para essas áreas: tratamentos caseiros da água, doenças adquiridas no contato com a água das inundações, famílias desabrigadas e perdas/recuperação de bens relacionados aos alagamentos e medidas de proteção nas residências contra as inundações. 


\section{RESULTADOS E DISCUSSÕES}

\subsection{O universo sistêmico: considerações sobre a ocupação, a configuração e os problemas ambientais da área de ocupação contínua do litoral do Paraná}

Uma das características da rede urbana brasileira é a configuração de áreas de ocupação contínua, definidas na escala de classificação da rede urbana pelo conjunto de municípios urbanizados, com contiguidade de mancha de ocupação, intensos fluxos de relações, complementaridade funcional, integração social e econômica (DESCHAMPS e KLEINKE, 2000, p.46). No litoral essas áreas estendem-se pela faixa litorânea e adquirem um padrão funcional próprio de balneários e das atividades portuárias, industriais e de serviços ali desenvolvidas.

De forma geral a ocupação e urbanização da costa brasileira, especialmente nos últimos 50 anos, derivaram em problemas socioambientais diversos. O litoral do Paraná, de certa forma reproduziu as premissas, as condicionantes e os processos que caracterizaram a ocupação e a urbanização litorânea do nosso país (ESTEVES, 2011, p. 62 a 80). Por estar inserido neste contexto, compartilha de problemáticas socioambientais urbanas similares a de outras regiões do litoral brasileiro.

No último século as atividades portuárias assumiram relevante papel na dinâmica regional e o crescimento e a modernização tecnológica e da sua infraestrutura tem acompanhado os ciclos econômicos do Estado. Essa influência, apesar do "divórcio" entre o porto e a cidade sede (GODOY, 2000), reflete na organização econômica, logística, industrial, urbana, territorial, social e, por conseguinte espacial de Paranaguá e de toda a região, aos quais se juntam os impactos socioambientais diretos e indiretos que se derivam de todos esses enlaces. Atualmente se projeta a expansão do sistema portuário para novos espaços, incluindo áreas protegidas pela legislação ambiental.

No início do século XXI a urbanização turística de segunda residência é um importante fator de produção de paisagem na costa brasileira, pela sua escala, dimensão e abrangência. A dinâmica mercantil que permeou a comercialização de terrenos destinados à ocupação por segundas residências foi caracterizada por intensa especulação imobiliária. Embora as praias paranaenses fossem frequentadas desde a década de 1920, a partir de 1950 o crescimento demográfico 


\section{ESTEVES, C. J. O. \\ VULNERABILIDADE SOCIOAMBIENTAL NA ÁREA DE OCUPAÇÃO CONTÍNUA DO LITORAL DO PARANÁ - BRASIL}

e econômico do Estado refletiu na procura pelos balneários. Nas últimas décadas do século $X X$ e início do XXI se instalaram dezenas de loteamentos destinados à ocupação por segundas residências. Esse tipo de ocupação resultou em problemas socioambientais de diversas ordens, onde podem se enumerar os associados à erosão costeira, interferências indevidas no sistema hídrico, expulsão de colônias de pescadores e problemas urbanos diversos (SAMPAIO, 2006, p. 169 a 186).

Levantamento feito por Esteves (2011, p. 108 a 128) indicou a quantidade de loteamentos regulares, irregulares e clandestinos existentes nos municípios balneários do litoral paranaense entre a década de 1940 e o final do século XX. Ao final dos anos de 1990 havia 102 loteamentos regulares, 32 irregulares e 21 clandestinos ou de natureza não identificada que abrigavam pelo menos 57.639 lotes destinados ao uso balneário. Em relação aos loteamentos de uso residencial permanente (ou uso misto com o fim balneário) no mesmo período foram levantados 24 regulares e 67 irregulares. Em ambos os casos (residencial permanente e segunda residência) houve forte atuação dos agentes da especulação imobiliária.

As expectativas de trabalho e renda criadas pelas atividades econômicas atraiu expressivo contingente de imigrantes ao litoral nas décadas de 1980 e 1990. Acrescenta-se a esse fator a saturação do mercado de trabalho na capital e região metropolitana, bem como o menor valor da terra nas áreas periféricas das cidades litorâneas ao se comparar com as cidades da Região Metropolitana de Curitiba (DESCHAMPS e KLEINKE, 2000; MOURA e WERNECK, 2000). Embora seja relativamente pequena ao se comparar com o conjunto do Estado, a população dos municípios do litoral aumentou, proporcionalmente, em nível superior à média do Paraná (ESTEVES, 2011, p.115 e 116). Para o período 1991-2000, enquanto no Estado houve um incremento médio de $13,2 \%$, na região o aumento foi de $34,8 \%$. Guaratuba e Matinhos tiveram percentuais de $51,4 \%$ e $113,5 \%$ e Paranaguá, $18,3 \%$. No período posterior (2000 a 2010) o índice também ficou acima da média estadual: $12,5 \%$ no litoral e $9,2 \%$ no Paraná. Guaratuba, Matinhos e Pontal do Paraná, registraram percentuais de $17,7 \%, 21,7 \%$ e $46,1 \%$. Se for considerar todo o período compreendido entre 1991 e 2010 , enquanto o Paraná teve um incremento de $23,6 \%$, no litoral a evolução foi de 51,7\%. Na mesma época foi aferido: $159,6 \%$ para Matinhos, $78,3 \%$ em Guaratuba e $30,4 \%$ à Paranaguá. Também é pertinente 
registrar o deslocamento sazonal de centenas de milhares de pessoas às cidades balneárias, especialmente no verão e em feriados prolongados.

O crescimento populacional demandou moradia para estas pessoas, assim como a procura do litoral enquanto espaço de veraneio e/ou lazer ensejou na necessidade de abrigo temporário. Isso fica nítido nos dados que atestam o extraordinário avanço dos domicílios particulares ocupados, destinados aos moradores permanentes, no período intercensos 1991/2010 e, no mesmo período, na evolução dos domicílios particulares não ocupados de uso ocasional que o IBGE associa às segundas residências (ESTEVES, 2011, p.121 e 122).

No período de 1991 a 2000 o incremento dos domicílios particulares ocupados (de uso permanente) foi na ordem de 51,4\% para a região litorânea. Os municípios com percentuais mais expressivos foram: Matinhos (138\%); Guaratuba (73\%) e Paranaguá (32\%). Para o período intercensos 2000/2010 foi apontada uma evolução de $24,1 \%$ para o litoral. Os maiores percentuais no período foram verificados em: Pontal do Paraná $(66,1 \%)$, Matinhos $(39,7 \%)$, Guaratuba $(35,5 \%)$ e Paranaguá (17\%). Entre 1991 e 2010, este tipo de domicílio avançou 87,8\% na região litorânea. Destacaram-se: Matinhos (232,5\%), Guaratuba (134,5\%) e Paranaguá (53,9\%). Pelos dados do censo 2010, a região litorânea comportava no ano de 2010 um total de 80.357 domicílios particulares ocupados.

Na década de 1990 houve expressivo incremento de domicílios particulares não ocupados de uso ocasional (segundas residências) no litoral: 61,3\%. As maiores taxas ocorreram em Pontal do Paraná com 280,9\%, Guaraqueçaba (92,9\%), Guaratuba (56,1\%), Morretes (53,4\%) e Matinhos (52,7\%). No período subsequente o incremento para o litoral foi de 15,7\%. Paranaguá, Guaratuba, Matinhos e Pontal do Paraná apresentaram respectivamente as seguintes taxas: $21,3 \%, 17,2 \%, 20,1 \%$, e $8,7 \%$. No período 1991-2010, cujo percentual na região foi $86,7 \%$, enumeram-se: Morretes com 150,8\%, Guaraqueçaba, 84,1\%; Matinhos, 83,4\%; Guaratuba 83\%. Em 2010, o litoral concentrava mais de 1/3 das segundas residências do Estado.

Somados os domicílios de uso ocasional e permanentes a outros tipos, destinados a variados usos, configurou-se nos municípios balneários e em Paranaguá a Área de Ocupação Contínua do Litoral do Paraná. No final da primeira década do século XXI consolidou-se a ocupação balneária. O morador permanente, 


\section{ESTEVES, C. J. O. \\ VULNERABILIDADE SOCIOAMBIENTAL NA ÁREA DE OCUPAÇÃO CONTÍNUA DO LITORAL DO PARANÁ - BRASIL}

especialmente o imigrante, por sua vez, tendeu a se estabelecer na periferia de Paranaguá e das cidades balneárias.

Ao transportar a concepção do SAU à escala da Área de Ocupação Contínua do Litoral do Paraná, as questões anteriormente analisadas relacionam-se aos atributos (subsistema social), e revelam as dinâmicas que influem na configuração desse aglomerado urbano (figura 3). Os elementos do subsistema social operam contínuas transformações socioespaciais as quais conduzem todo 0 sistema a um amiúde reequilíbrio dinâmico. A dinâmica social reorganiza dialeticamente as entradas (inputs) do SAU, que ocorrem pelo subsistema construído, notadamente o componente habitação (permanentes e temporárias) e demais infraestruturas logísticas e urbanas, desencadeando novas saídas (outputs).

Os componentes do subsistema construído, bem como as dinâmicas sociais que thes ensejam permanentes transformações, se distribuem e interagem sobre (e com) uma base natural, representados pelos elementos correspondentes às entradas do subsistema natural (figura 2). Na Área de Ocupação Contínua do Litoral do Paraná, de forma geral, dois componentes caracterizam o relevo: a Serra do Mar e a Planície Litorânea (ESTEVES, 2011), que por sua vez é constituída por formações arenosas, paludais terrestres e manguezais. O elemento solo se associa a unidade fisiográfica ao qual se assenta. Na planície predominam os componentes Espodossolos, Gleissolos e os Organossolos (EMBRAPA e IAPAR, 2008, p. 52). As concavidades dos cordões arenosos comumente são áreas de banhados, pois naturalmente tendem a acumular água devido à característica do terreno e pelo afloramento do lençol freático associado à incidência dos Espodossolos Humilúvicos Hidromórficos. Nas áreas urbanas, o elemento vegetação, bastante alterado, se relaciona as formações típicas de restinga, mangues, banhados e matas ciliares, com remanescentes da mata atlântica, preservados especialmente nas Unidades de Conservação.

O clima no Litoral do Paraná é classificado como pertencente ao domínio Subtropical-Úmido com Inverno Fresco a Frio. O comportamento dos seus componentes é regido pelos atributos da dinâmica natural, notadamente a posição latitudinal, as características físicas regionais, pelos sistemas atmosféricos atuantes na região e à dinâmica do Oceano Atlântico. As maiores médias de temperatura e 
precipitação ocorrem no verão. Todavia, em outras épocas do ano registram-se episódios de temperaturas elevadas e de chuvas intensas e concentradas (VANHONI, 2009).

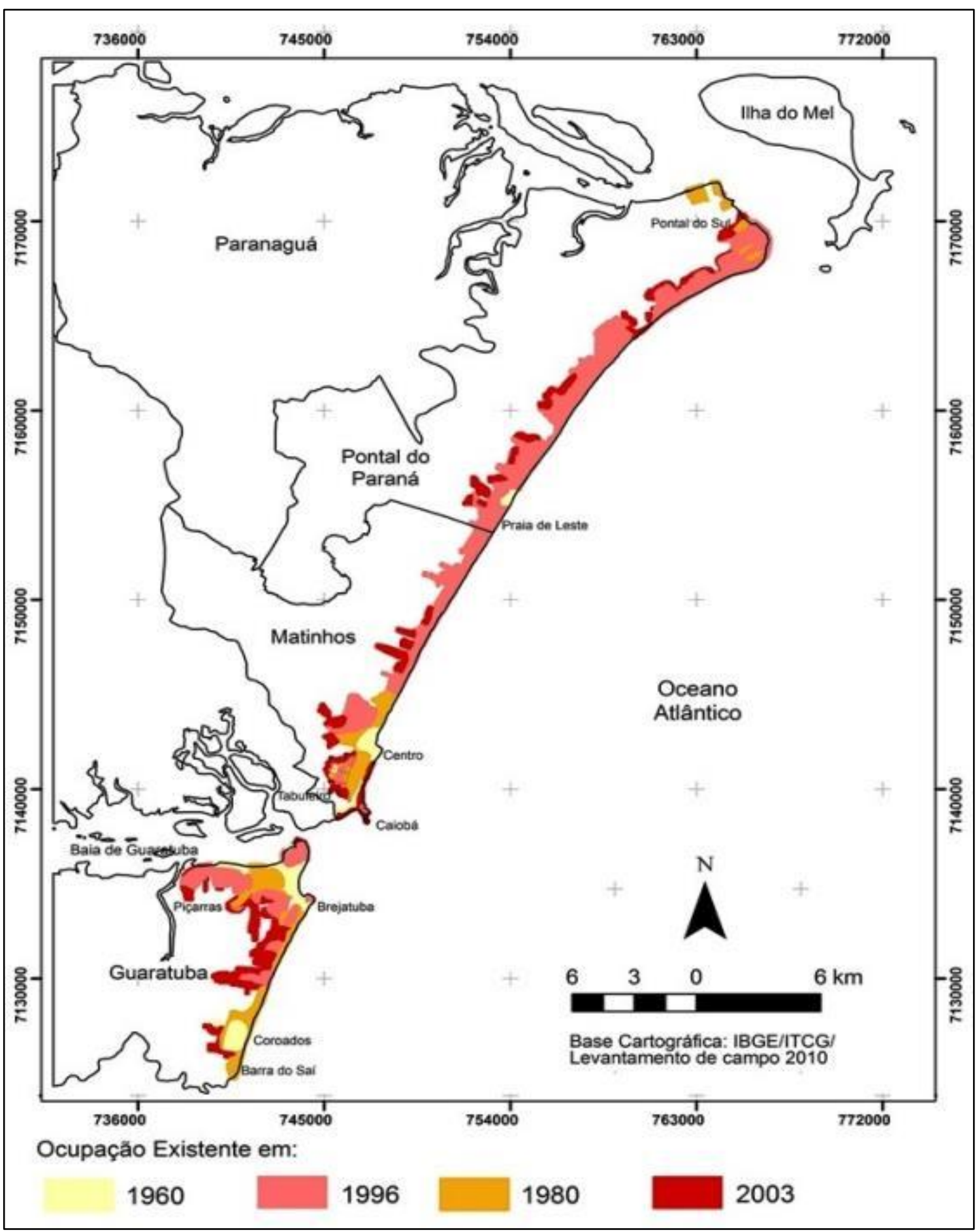

Figura 3 - Evolução urbana dos municípios da área de ocupação contínua do litoral do Paraná 1960/1980/1996/2003.

Organização: ESTEVES e VANHONI (2010); ESTEVES e ZANINELLI (2014) 


\section{ESTEVES, C. J. O. \\ VULNERABILIDADE SOCIOAMBIENTAL NA ÁREA DE OCUPAÇÃO CONTÍNUA DO LITORAL DO PARANÁ - BRASIL}

Os inputs provenientes do elemento hidrografia se associam as águas do mar, dos rios, córregos, marigots, gamboas e demais corpos aquosos que se inserem na Bacia Hidrográfica do Litoral do Paraná (sub-bacia da Bacia Atlântica) e ao lençol freático. A par dos processos de transferências inerentes ao ciclo hidrológico é notória a influência da cinética oceânica sobre os demais componentes deste elemento, especialmente na determinação da direção do fluxo do escoamento das águas superficiais e no nível do lençol freático. Também há forte interação com as instâncias dos subsistemas construído e social, a exemplo das intervenções levadas a cabo a partir da década de 1950 quando iniciou a construção de canais destinados à urbanização e ao saneamento. A intensificação da ocupação e a ampliação dos canais artificiais resultaram em um quadro de alterações radicais na rede hidrográfica superficial, resultando em mudanças na circulação de matéria e energia associada ao elemento água. As intervenções incluíram a ocupação de áreas naturalmente inundáveis, desmatamento de matas ciliares, aterramentos de rios e banhados, desvios, junção, canalização e retilinização de cursos hídricos, formação de diques artificiais pela construção de estradas, instalação de tubulações com diâmetro inadequado, impermeabilizações, assoreamento, lançamento de efluentes, entre outras (ESTEVES, 2011).

Das interações e transformações operadas no interior do SAU resultam as saídas (outputs). Na escala de análise sistêmica transposta aos municípios da Área de Ocupação Contínua do Litoral do Paraná, destacam-se as inundações urbanas e a degradação ambiental decorrente do destino inadequado do esgoto.

As inundações urbanas acontecem quando entra no SAU grande volume de matéria (água) e energia nos episódios de chuvas intensas e concentradas (ESTEVES, p. 188 a 207). Outra condicionante natural é quando simultaneamente ao evento chuvoso ocorre o represamento de água pela enchente da maré cheia. $A$ coincidência dessas duas dinâmicas tende a acumular matéria no interior da planície, e a dispersão da água é condicionada pela diminuição da chuva e pela vazante da maré. Aos fatores advindos das entradas e dinâmicas naturais interagem os elementos filiados aos subsistemas construído e social, notadamente os componentes provenientes das interferências na rede hidrográfica e dos impactos advindos da ocupação, especialmente a ocorrida em áreas naturalmente inundáveis. 
Em levantamento realizado por Esteves (2011, pgs, 189 e 192) para o período compreendido entre 1979 e 2010 com base no registro diário das datas de ocorrência dos maiores volumes de precipitação no litoral do Paraná, foram identificados diversos eventos de inundações nos municípios balneários, particularmente em Matinhos. Algumas foram noticiadas pela mídia e evidenciaram as problemáticas associadas às inundações urbanas na região (ESTEVES, 2011, p. 189 a 195). No espaço temporal desta pesquisa as últimas inundações no litoral com forte repercussão aconteceram em 2010 e 2011. Em 08/01/2010, quando foram medidos 215,2 mm de precipitação, estimou-se 400 residências avariadas em Matinhos (ESTEVES, 2011, p. 191). Em março de 2011 foram atingidos Morretes, Antonina, Guaratuba e Paranaguá. Os dois primeiros decretaram "estado de calamidade" pública e os outros dois "estado de emergência".

Outra problemática socioambiental na Área de Ocupação Contínua do Litoral do Paraná se vincula à precariedade da rede pública de coleta de esgotos. Em 2010 somente $45 \%$ dos domicílios de Guaratuba eram atendidos pela rede de coleta, percentuais que atingiam 43\% em Matinhos e 21\% em Pontal do Paraná. Em relação aos domicílios conectados a rede de esgotos os percentuais eram inferiores: 32\% em Guaratuba, 20\% em Matinhos e em Pontal do Paraná 16\% (ESTEVES, 2011, p. 178 e 179)

O destino inapropriado dos esgotos se associa ao contágio por uma série de doenças. Um demonstrativo da quantidade de internações hospitalares (pelo SUS) na região, entre 1998 e 2011, por causa de doenças infecciosas cujo contágio presumível ocorreu pela ingestão ou contato com água contaminada indica que foram registrados no período 2370 internações (ESTEVES, 2011, p. 183). Entre as morbidades foram registrados casos de doenças infecciosas intestinais (1700 casos), Diarreia e Gastroenterite (475) Hepatites (158) e Leptospiroses (46).

\subsection{Aspectos da Ocupação Permanente no Tabuleiro I e II e na Vila Nova}

As trocas sinérgicas de matéria e energia, em diferentes graus de complexidade e intensidade, ocorrem com todos os níveis do universo ao qual o SAUMTVN está inserido. Os atributos inerentes às dinâmicas da sociedade ensejam 


\section{ESTEVES, C. J. O. \\ VULNERABILIDADE SOCIOAMBIENTAL NA ÁREA DE OCUPAÇÃO CONTÍNUA DO LITORAL DO PARANÁ - BRASIL}

fortes relações do SAUMTVN especialmente às dinâmicas do ambiente urbano de Matinhos.

Destaca-se que a atividade turística é um elemento importante na organização espacial, social, econômica e ambiental. Embora sazonal, o turismo de sol e praia influiu na definição, pelo mercado imobiliário, no maior valor do preço das áreas situadas próximas às praias, em contraposição as localizadas no interior da planície a exemplo da região do Tabuleiro e da Vila Nova. A atividade turística também dinamizou a construção civil, setor cujas expectativas de trabalho e renda atraiu contingente de imigrantes no último vicênio do século $X X$.

A ocupação do Tabuleiro I e II e da Vila Nova ocorreu de variadas formas. Houve loteamentos estabelecidos legalmente e outros que são considerados irregulares. Também ocorreu sobreposição de loteamentos, conflitos fundiários e ocupações de terra (PARANÁ e MATINHOS, 2006, p. 190 e 191) ${ }^{4}$. No final do século $X X$ a região do Tabuleiro foi a de maior incremento populacional no município com forte adensamento ocupacional (MOURA e WERNECK, 2000). Dados coletados na área de abrangência do SAUMTVN indicaram que 19,3\% dos chefes de família haviam nascido em Matinhos enquanto 80,7\% eram imigrantes (Destes, 31,1\% oriundos do interior do Paraná e $23,2 \%$ de Curitiba/RMC). Com relação ao tempo de moradia, do universo dos entrevistados, $62 \%$ moravam, na época da pesquisa, há mais de 10 anos no local. (ESTEVES, 2011, p. 140)

No Tabuleiro I e II e na Vila Nova predomina uma população de baixa renda. Todavia a área não é homogênea (ESTEVES, 2011, p. 145 a 147). De forma geral a Vila Nova é mais carente do que o Tabuleiro I e II (ESTEVES, 2011, p. 231 a 249). $\mathrm{Na}$ área representada pelo SAUMTVN identificam-se aglomerados habitacionais precários (entradas do subsistema construído), geralmente situados nos loteamentos irregulares, como no caso de áreas da Planta Maria Ivone Alonso, do Jardim Ross e da Vila Municipal e nos loteamentos clandestinos. Indubitavelmente

\footnotetext{
${ }^{4}$ Regulares: Cidade Balneária Caiubá (1950), Cidade Balneária Caiubá - Parte II (1950), o Loteamento Felipe Mendes (1955), Loteamento Bela Vista (1967); Irregulares: Balneário Banhomar (1995), Celina Mendes (1992), Jardim Ross - parte 02 (1982), Planta Ivone Maria Alonso (1992), Planta João Carraro (1992), Planta Marcos Antonio Podbevsek (1996), Vila Municipal - Tabuleiro (1999), Jardim Juliana (1995); Clandestinos: o Jardim Itacolomi e o Loteamento Juvêncio Ramos, enquanto o Loteamento Boqueirão de Matinhos não foi classificado.
} 
os locais mais carentes é a área conhecida como Risca Faca (Vila Nova) e o Jardim Itacolomi (Tabuleiro I).

\subsection{Entradas, atributos e saídas do SAUMTNV: a vulnerabilidade socioambiental no Tabuleiro I e II-Vilanova}

O risco é uma categoria de análise relacionada às ideias de incerteza, exposição ao perigo e a eventualidade da ocorrência de desastres. Como risco ambiental podem ser considerados a contingência de acontecimentos como: deslizamentos, enchentes/inundações, as diversas formas de contaminação, seja por via atmosférica ou hídrica, ou ainda as decorrentes do contato com o lixo, entre outras. A possibilidade de perdas, que é inerente ao risco, possui uma dimensão espacial. Assim, um evento desastroso pode resultar em danos materiais, doenças e até perda de vidas humanas em sua área de ocorrência. Do ponto de vista sistêmico a ocorrência de um desastre significa a ruptura de uma trajetória na reprodução do sistema, seguido por um rearranjo no seu interior ou até mesmo na organização de uma nova estrutura sistêmica (BRUNET, et. al. 1993).

Enquanto o risco é um componente da vulnerabilidade que se associa ao perigo, a vulnerabilidade representa a sensibilidade ou a suscetibilidade a algum tipo de dano e pode ser analisada como uma situação em que estão presentes três elementos: a exposição ao risco; a capacidade de reação e o grau de adaptação diante da materialização do risco (VEYRET e REGHEZZA, 2006, p. 11 e 12), sendo que os dois últimos podem ser componentes associados à capacidade de resposta a eventos danosos e desastres (MARANDOLA JR. e HOGAN, 2006, p. 34).

A vulnerabilidade de uma comunidade pode ser designada por uma situação de risco, ou um conjunto deles, e se insere em um contexto que envolve fatores econômicos, sociais, culturais e ambientais. Geralmente as parcelas da população com níveis elevados de privação econômica e social são mais vulneráveis (KAZTMANN e FILGUERA, 1999). Além das carências econômicas outras componentes que definem a vulnerabilidade social se associam a qualidade das habitações, faixa etária, condições de saúde, relações de gênero e a elementos presentes nas discriminações e nos preconceitos étnico-raciais, de identidade de gênero, entre outros. 
Thouret e D'Ercole (1996, p. 409 e 410) apontam algumas causas que tornam amplas parcelas da população urbana dos países de desenvolvimento tardio vulneráveis aos riscos ambientais: a) acelerada expansão urbana que proporcionou o avanço das cidades sobre encostas, planícies inundáveis e áreas sujeitas a eventos sísmicos; b) fatores que promovem o desequilíbrio no desenvolvimento socioeconômico e territorial, incluindo as políticas habitacionais e de controle sobre 0 uso do solo, que acabam segregando as populações mais carentes; c) as condições de vulnerabilidade são agravadas por fatores como a impermeabilização, a construção de habitações em áreas de risco, entre outros.

Dependendo do enfoque a vulnerabilidade ambiental pode ser concebida como o grau de susceptibilidade natural de um ambiente em si, ou, resultante do impacto provocado por um uso qualquer. Neste trabalho a ideia de vulnerabilidade ambiental segue a tradição desse conceito no campo da geografia brasileira que a relaciona com a extensão da manifestação espacial dos riscos e das situações de degradação ambiental em determinada área (ALVES, 2006, p. 47)

\subsection{Vulnerabilidade Ambiental: Configuração das Áreas de Riscos Ambientais Relacionadas às Inundações e as Situações de Degradação Ambiental}

$\mathrm{Na}$ pesquisa de campo ficou constatado que a maioria dos domicílios visitados $(60 \%)$ já havia sido alagado devido às inundações urbanas. Do total de entrevistados $27 \%$ já tivera a sua casa alagada mais que cinco vezes e $43 \%$ três episódios ou mais (ESTEVES, 2011, p. 254). O mapa da figura 4 demonstra pequenas áreas no Tabuleiro I e II, localizadas distantes dos canais e em posição topográfica mais elevada, consideradas como de baixo risco. De forma geral as porções de médio risco situam-se no interior do Tabuleiro I e II e ao sul da Vila Nova. As áreas de alto risco estão mapeadas nas porções limítrofes, acompanhando o canal do Milhomem (ao norte) e o canal da Avenida JK. O Tabuleiro I e a Vila Nova são as localidades com maiores partes das suas superfícies na condição de alto risco, enquanto no Tabuleiro II predominam áreas de médio risco. 


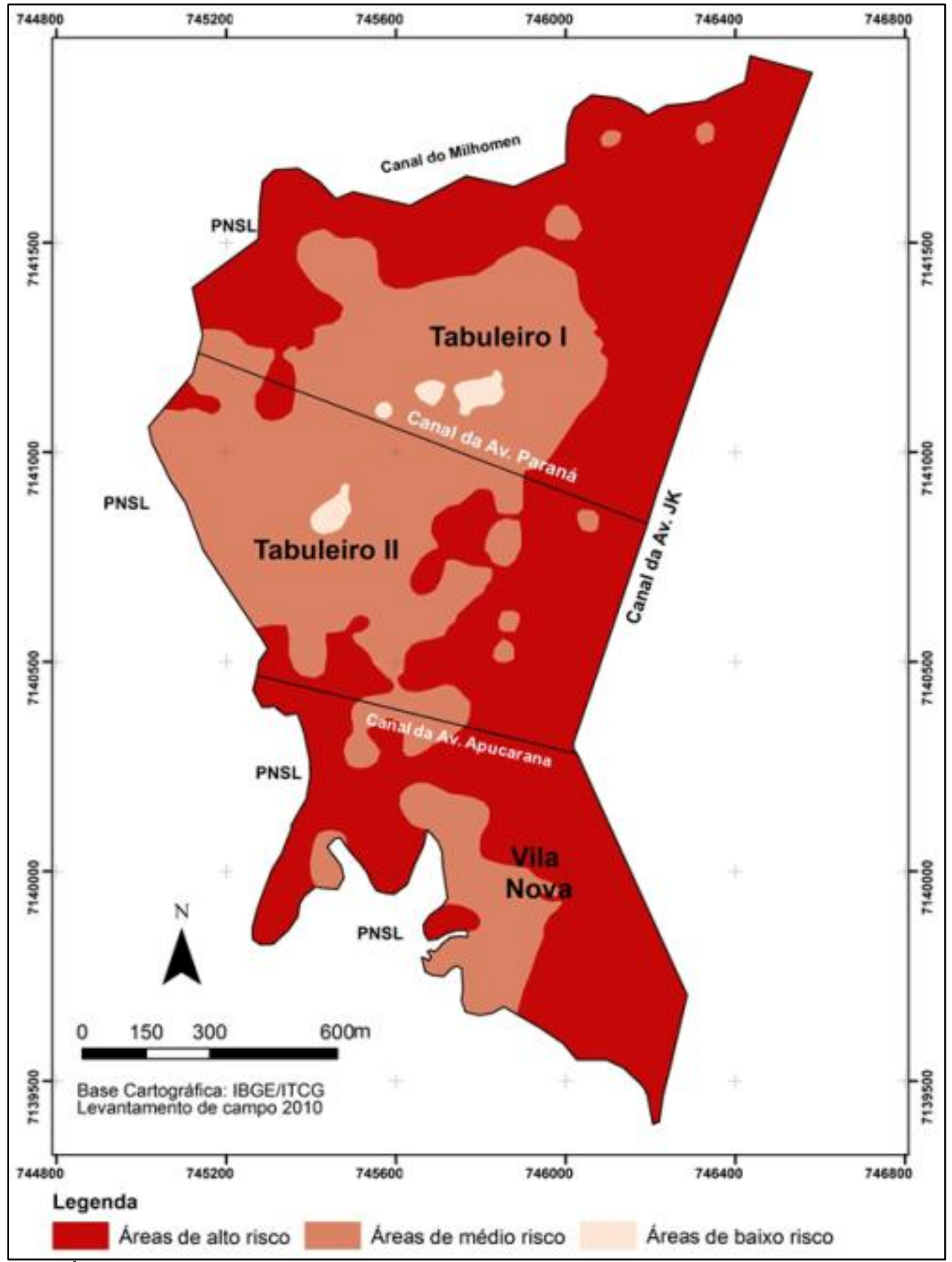

Figura 4 - Áreas de risco do SAUMTVN, delimitadas segundo a quantidade de inundações nos domicílios - Matinhos.

Organização: ESTEVES e VANHONI (2011); ESTEVES e ZANINELLI (2014)

A rede coletora de esgotos, representada na figura 5 pelo retângulo azul, abrange uma porção do Tabuleiro II e esta área foi categorizada como de baixa degradação. As demais áreas foram consideradas de alta degradação ambiental. 


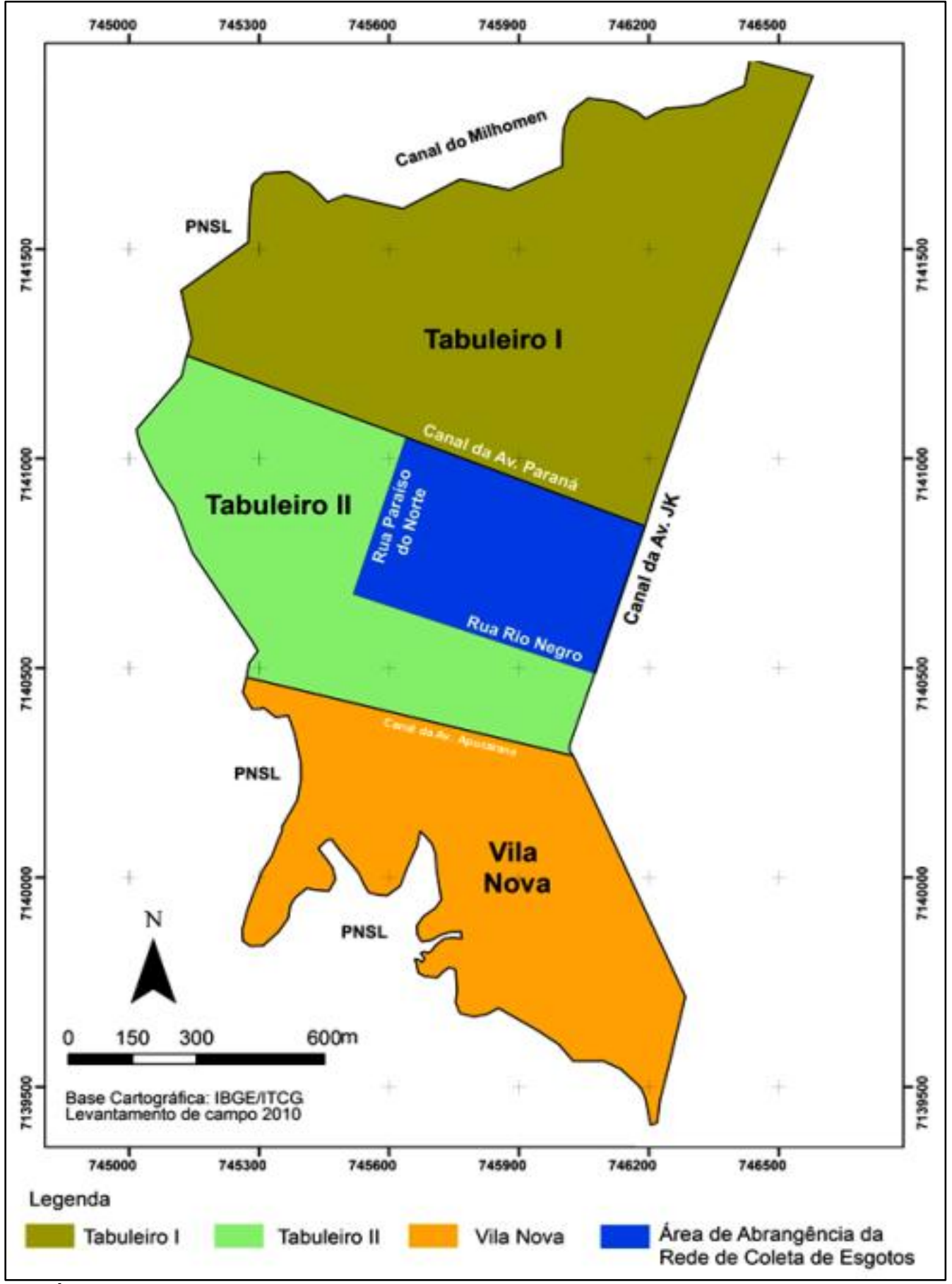

Figura 5 - Área de abrangência da rede coletora de esgotos no SAUMTVN - Matinhos. Organização: ESTEVES, VANHONI (2011); ESTEVES e ZANINELLI (2014)

Neste trabalho a vulnerabilidade ambiental é concebida como saída (input) do SAUMTVN e resulta da sobreposição espacial das situações de risco e degradação ambiental. No mapa da Figura 6 visualiza-se que a maior parte da superfície de abrangência do SAUMTV foi considerada como de Alta ou de Média/Alta Vulnerabilidade Ambiental. 


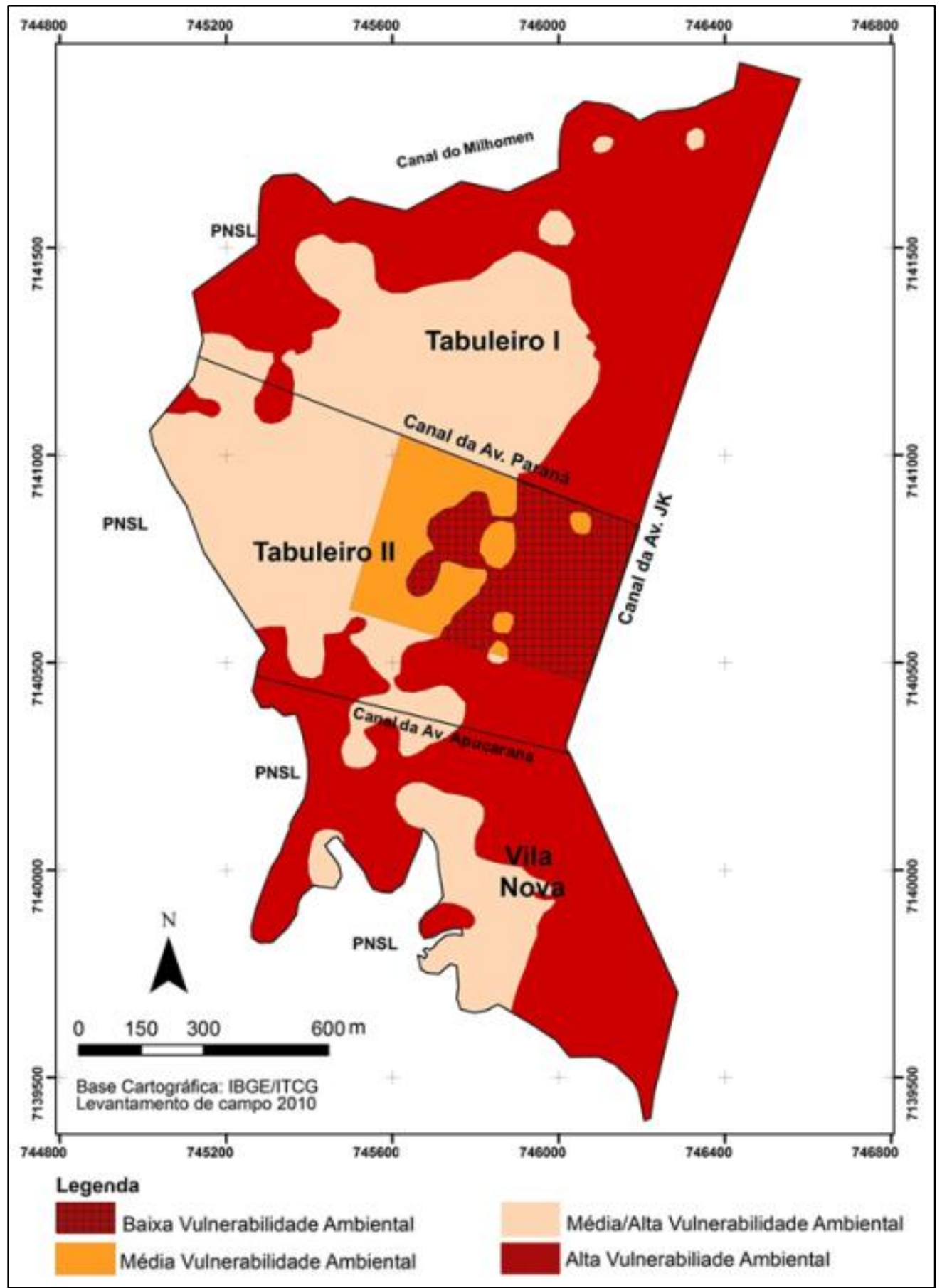

Figura 6 - Mapeamento das categorias de vulnerabilidade ambiental - SAUMTNV- Matinhos Organização: ESTEVES, VANHONI (2011); ESTEVES e ZANINELLI (2014)

As áreas de Alta Vulnerabilidade Ambiental estão mapeadas especialmente no Tabuleiro I e na Vila Nova. No Tabuleiro I se estendem pelas porções situadas próximas à Avenida JK e nas áreas adjacentes ao canal do Milhomem e aos limites com o PNSL (Parque Nacional Saint-Hilaire/Lange). Na Vila Nova nas porções oeste e sul, margeando o PNSL e próximas à Av. JK. Também se identificou áreas de Alta 
Vulnerabilidade Ambiental no Tabuleiro II em praticamente toda a extensão do limite com a Vila Nova. As áreas de Média/Alta Vulnerabilidade estão situadas no interior do Tabuleiro I, II e da Vila Nova.

\subsection{Vulnerabilidade Socioambiental no SAUMTVN: A Integração da Dimensão Social da Vulnerabilidade com a Dimensão Espacial da Vulnerabilidade Ambiental}

Ao integrar as dimensões sociais e ambientais na identificação e análise da vulnerabilidade, é pertinente a adoção da terminologia vulnerabilidade socioambiental. Essa premissa se justifica porque a vulnerabilidade aos riscos ambientais depende de fatores sociais, econômicos, tecnológicos, culturais, ambientais e a relação desses com o ambiente físico-natural, envolvendo, portanto, a dinâmica social e a dinâmica ambiental, com a última, inclusive, quando em estado de degradação (MENDONÇA, 2011). Neste item se analisa a vulnerabilidade social pelas categorias de vulnerabilidade ambiental, operacionalizando as situações de vulnerabilidade socioambiental na área representada pelo SAUMTVN, segundo o pressuposto defendido por Alves (2006, p. 43) para esta dimensão da vulnerabilidade.

Quanto ao universo familiar dos entrevistados ficou revelado que a maioria habitava em domicílios situados nas áreas de Alta Vulnerabilidade Ambiental: 563 pessoas ( $52 \%$ do total). Nas áreas de Média/Alta Vulnerabilidade Ambiental a pesquisa alcançou 354 pessoas (33\%). Nas áreas de Média e de Baixa Vulnerabilidade Ambiental abrangeu 91 e 78 pessoas (ESTEVES, 2011, p. 249). Das famílias pesquisadas nos locais de Alta Vulnerabilidade Ambiental, 76\% morava há menos de 15 anos no domicílio (ESTEVES, 2011, p. 250), o que pode indicar que as áreas menos vulneráveis do ponto de vista ambiental foram ocupadas primeiro. Nas áreas de Alta Vulnerabilidade Ambiental foi detectado maior presença de mulheres nas estruturas familiares (53\%). Em boa parte dos domicílios havia pelo menos um membro pertencente aos grupos etários mais vulneráreis (crianças, adolescentes e idosos). Ao juntar estes grupos $82 \%$ das famílias entrevistadas nas áreas de Alta Vulnerabilidade Ambiental possuía ao menos um membro em uma dessas faixas de idade (ESTEVES, 2011, p. 251 e 252). 


\section{VULNERABILIDADE SOCIOAMBIENTAL NA ÁREA DE OCUPAÇÃO CONTÍNUA DO LITORAL DO PARANÁ - BRASIL}

Nos locais de Média Vulnerabilidade Ambiental 54\% dos entrevistados declararam que a sua residência já fora inundada mais de cinco vezes enquanto que nas áreas de Alta Vulnerabilidade Ambiental esse percentual foi de $40 \%$. Ao considerar o total dos registros da ocorrência de cinco inundações ou mais (81 registros), e efetuar a sua distribuição pelas categorias de vulnerabilidade ambiental, a maior parte (58 registros ou $72 \%$ do universo amostral) haviam ocorrido em domicílios das áreas de Alta Vulnerabilidade Ambiental (ESTEVES, 2011, p. 253 e 254). Relatos descreveram momentos vividos nessas ocasiões: "No começo de 1999, foi a pior (...). A gente só não saiu, foi pro abrigo, porque ficou dentro do carro. Se trancou, mas dava medo que o carro fosse arrastado.". (PAULUK, 2009, comunicação pessoal). Em algumas situações foi necessária a intervenção do corpo de bombeiros: "Na enchente, uns dois anos atrás, fui resgatada de casa pelos bombeiros, não estava conseguindo sair." (CORREA, comunicação pessoal, 2009).

As áreas de Alta e de Média/Alta Vulnerabilidade Ambiental não possuíam rede de coleta de esgoto. Mesmo dispondo do serviço apenas $43 \%$ dos domicílios estavam conectados à rede nas áreas de Baixa Vulnerabilidade Ambiental e 63\% nas de Média Vulnerabilidade Ambiental. Para as áreas de Média/Alta e de Alta Vulnerabilidade Ambiental prevaleciam as fossas sépticas: 53\% e 44\% (ESTEVES, 2011, p. 257 a 259). Também eram utilizadas fossas rudimentares, mais danosas ao ambiente que as sépticas, pois os fluídos ficam em contato direto com o solo e também porque quando a fossa satura há o vazamento para a superfície: "Quando a maré sobe, ou chove demais, eleva o nível do lençol freático isso faz com que as fossas vazem porque o nível do líquido lá dentro sobe também" (SOUZA, 2009, comunicação pessoal). Devido à dinâmica natural: "Não dá para fazer fossa porque o lençol freático é muito raso, se cavar 50 centímetro verte água. Devia ser proibido porque contamina o lençol freático." (TONON, 2009, comunicação pessoal).

Nas áreas de Alta Vulnerabilidade Ambiental o percentual de domicílios que enviava o esgoto diretamente para os rios e canais do SAUMTVN era de $10 \%$, para as valetas $17 \%$ e para a rede de águas pluviais $8 \%$ (ESTEVES, 2011, p. 257): "Aqui não passa a rede, por isso que jogam o esgoto no canal da Avenida Paraná. (...). Quando faz calor é um cheiro que ninguém aguenta. O pior é quando dá enchente e a água suja invade as casas." (MENDES, 2009, comunicação pessoal). Dos 42 


\section{VULNERABILIDADE SOCIOAMBIENTAL NA ÁREA DE OCUPAÇÃO CONTÍNUA DO LITORAL DO PARANÁ - BRASIL}

entrevistados que afirmaram contágio por via hídrica no contato com a água das inundações, 40 (ou 93\% do total) habitavam nas áreas de Alta ou de Média/Alta Vulnerabilidade Ambiental e os outros $3 \mathrm{em}$ áreas de Média Vulnerabilidade Ambiental (ESTEVES, 2011, p. 260). Nas áreas de Alta Vulnerabilidade que se registraram os três óbitos decorrentes de leptospirose. $O$ poder de reação e adaptação da população frente a estas situações é frágil. Em parte isto decorre das condições de atendimento no único hospital da cidade: "Deus me livre parar no hospital aqui em Matinhos (...). Tem gente que pega infecção, sai pior do que entrou isso se não morrer. No posto de saúde o atendimento é melhor as enfermeiras se esforçam, mas falta tudo (...)." (MORAES, 2009, comunicação pessoal). Diante dessa situação alguns moradores buscam se prevenir para não adquirirem doenças, mesmo que de forma não convencional: "Quando enche, não saio de casa para não pegar doença. (...). Não quero ir para o Hospital aqui porque é uma porcaria.(...). Eu crio uma cobra no quintal por causa dos ratos, ela não é venenosa e come os ratos." (MARQUES, 2009, COMUNICAÇÃO PESSOAL).

Nas áreas de Média e de Baixa Vulnerabilidade Ambiental praticamente todos os domicílios dispunham de água tratada. Nas áreas de Alta e de Média/Alta Vulnerabilidade Ambiental cerca de $80 \%$ dos domicílios estavam conectados à rede pública de abastecimento de água (ESTEVES, 2011, p. 257). Os demais captavam água de poços e nascentes canalizados (20\% na de Alta e $14 \%$ nos de Média/Alta) ou sem canalização ( $3 \%$ na de Média/Alta).

Em toda a área representada no SAUMTVN já houve desabrigados devido às inundações. Dos 30 casos de famílias desabrigadas, 22 (73\%) foi levantado nas áreas de Alta Vulnerabilidade Ambiental, onde também ocorreu a maior parte dos registros de perda de bens materiais por conta das inundações (ESTEVES, 2011, p. 262 e 263): "Quando começa a encher corro levantar os móveis é a primeira coisa, o que pode salvar a gente salva. A geladeira tem que tirar as coisas de dentro e abrir a porta para ela não sair boiando. (CAMARGO, 2009, comunicação pessoal).

A maioria das famílias que havia perdido bens nas inundações recuperou-os, ainda que parcialmente. Nas áreas de Alta Vulnerabilidade Ambiental 43\% recuperaram seus bens integralmente (ESTEVES, 2011, p. 263), $16 \%$ teve recuperação quase total e 22\% parcialmente (ESTEVES, 2011, p. 264). Dos 10 


\section{ESTEVES, C. J. O. \\ VULNERABILIDADE SOCIOAMBIENTAL NA ÁREA DE OCUPAÇÃO CONTÍNUA DO LITORAL DO PARANÁ - BRASIL}

entrevistados que nada haviam recuperado, quatro eram das áreas de Alta Vulnerabilidade Ambiental (ESTEVES, 2011, p. 264). Geralmente quem conseguiu recuperar os bens o fez com recursos próprios. Isso aconteceu respectivamente com $100 \%, 85 \%$ e $81 \%$ das famílias dos entrevistados para as áreas de Média/Alta, de Média e de Alta Vulnerabilidade Ambiental. Dos 11 entrevistados que declararam que a recuperação dos bens foi com o auxílio de doações, 10 moravam nas áreas de Alta Vulnerabilidade Ambiental (ESTEVES, 2011, p. 264).

A recuperação dos bens comumente causa endividamento às famílias: "A gente não vive sem geladeira e fogão que ainda estou pagando da enchente do ano passado. A TV não foi porque levantei (...). O guarda roupa meu filho que me deu." (DUARTE, 2009, comunicação pessoal). Entre os 35 casos levantados em campo, onde o prazo para recuperar os bens excedeu a um ano, 30 (86\%) foram registrados nas áreas de Alta Vulnerabilidade Ambiental (ESTEVES, 2011, p. 264 e 265). Algumas famílias que sofreram danos materiais preferiram investir na reforma da casa visando à prevenção na eventualidade de outros eventos desastrosos: "Perdi quase tudo (...). Recuperei pouca coisa, preferi investir na casa, levantei para a água não entrar, fiz de alvenaria, ainda estou fazendo." (CAMARGO, 2009, comunicação pessoal).

Praticamente metade dos domicílios possuía algum tipo de proteção contra inundações, especialmente obras de contenção e drenagem. As diversas formas se faziam mais presentes em casas localizadas nas porções de Alta (59\%), de Média (41\%) e de Média/Alta (34\%) Vulnerabilidade Ambiental (ESTEVES, 2011, p. 266). Situação preocupante na região é o das casas que não têm nenhum tipo de proteção contra as inundações, caso de $41 \%$ dos domicílios pesquisados nas áreas de Alta Vulnerabilidade Ambiental (ESTEVES, 2011, p. 267). Essas habitações são consideradas as mais vulneráveis (CHENESSEAU et al., 2007).

Nas áreas de Alta Vulnerabilidade Ambiental 78\% dos entrevistados declarou que a renda familiar era menor que um três salários mínimos mensais (S.M.M.), com $15 \%$ na faixa inferior a um S.M.M.. Na faixa de rendimento inferior a três S.M.M. para as áreas de Média/Alta Vulnerabilidade houve $65 \%$ de afirmativas, com $9 \%$ declarando renda menor que um S.M.M.. Para as porções de Baixa Vulnerabilidade Ambiental os percentuais indicaram $62 \%$ com renda familiar abaixo de três S.M.M. 
(14\% inferior a um S.M.M.) Nas áreas de Média Vulnerabilidade Ambiental foram $58 \%$ que afirmaram ter renda menor que três S.M.M. e $8 \%$ declararam rendimento familiar inferior a um S.M.M.. (ESTEVES, 2011, p. 271 e 272)

Do conjunto da pesquisa verificou-se que nas áreas de Alta Vulnerabilidade Ambiental habitavam as famílias com menor renda. Nessas áreas residiam $63 \%$ do total de entrevistados (35) que declararam renda familiar inferior a um S.M.M. e 57\% dos 199 que afirmaram renda familiar menor que três S.M.M. (ESTEVES, 2011, p. 271 e 272). Nas áreas de Alta Vulnerabilidade Ambiental os dados revelaram que a maior parte dos alagamentos nas residências havia ocorrido entre famílias com renda inferior a três S.M.M. (77 \% dos que haviam sofrido ao menos uma inundação). Em relação à doenças/óbitos na família pelo contato com a água contaminada das inundações essa faixa salarial respondeu por $97 \%$ dos agravos (ESTEVES, 2011, p. 272).

\section{CONSIDERAÇÕES FINAIS}

A problemática retratada neste estudo, resguardada a dimensão escalar do recorte espacial da pesquisa, insere-se no contexto da crise ambiental atual, a qual, por sua vez, se constitui em uma das dimensões da crise civilizatória contemporânea (SACHS, 2011). Neste contexto, as situações de vulnerabilidade socioambiental observadas nas periferias das cidades exprimem conflitos resultantes das complexas interações entre a sociedade e a natureza no ambiente urbano.

Os estudos das problemáticas ambientais que concebem a sociedade e a natureza enquanto elementos que interagem no mesmo processo constituem 0 campo de investigação da geografia socioambiental (MENDONÇA, 2002). A proposta do SAU propõe uma abordagem "integrada, holística e conjuntiva" para os problemas socioambientais urbanos (MENDONÇA, 2004, p. 205), demonstrando ser uma metodologia apropriada para os estudos de vulnerabilidade socioambiental nas áreas urbanas.

Neste estudo identificou-se um permanente e sinérgico fluxo de matéria e energia entre o SAUMTVN e o seu universo sistêmico, especialmente com o Município de Matinhos e a Área de Ocupação Contínua do Litoral do Paraná. Destes 


\section{ESTEVES, C. J. O. \\ VULNERABILIDADE SOCIOAMBIENTAL NA ÁREA DE OCUPAÇÃO CONTÍNUA DO LITORAL DO PARANÁ - BRASIL}

fluxos resultam os elementos representados pelas entradas (inputs), atributos e as saídas (outputs). Os elementos presentes no ambiente urbano, caracterizados como entradas do SAUMTVN compuseram um subsistema natural e outro construído os quais, em constante e dialética interação, são movimentados pelos atributos sistêmicos referentes às dinâmicas da sociedade e da natureza (incluído os episódios abruptos como as chuvas concentradas).

Das interações e conflitos entre os elementos destes subsistemas resultam as saídas do sistema, entendida como a gama de componentes que interagem tipificando as condições que caracterizam a alta vulnerabilidade socioambiental. Estas saídas podem ser identificadas por alguns elementos como: inundações, degradação ambiental associada às carências da rede coletora de esgotos, ocupações clandestinas/irregulares, favelamento e moradias precárias, pobreza, patogenias/óbitos decorrentes das condições socioambientais, entre outras.

As situações de alta vulnerabilidade socioambiental ficam mais evidenciadas nas áreas que foram delimitadas (categorizadas) como de Alta Vulnerabilidade Ambiental (FIGURA 6). Estas áreas, que ocupam a maior porção da região representada pelo SAUMTVN, resultam da interação espacial entre as áreas de alto risco ambiental associado às inundações (FIGURA 5) com as de alta degradação ambiental que corresponde a toda parcela não atendida pela rede pública de coleta de esgotos (FIGURA 5).

Entre os moradores entrevistados nas áreas de Alta Vulnerabilidade Ambiental, $69 \%$ declararam que a sua residência já havia sido alagada três vezes ou mais, com significativo registro de perdas materiais e desabrigados. Estas áreas não dispunham de rede pública de coleta de esgotos. Os dejetos eram destinados para fossas sépticas ( $44 \%$ das respostas), rudimentares $(21 \%)$ ou ainda valetas, córregos e canais (35\%).

Ficou constatado que as inundações na área representada pelo SAUMTVN, bem como no recorte correspondente ao seu universo sistêmico, originam-se na associação entre chuvas intensas e concentradas, e as problemáticas advindas da urbanização e as intervenções inadequadas na rede de drenagem. A questão do destino inadequado dos esgotos produzidos nos domićlios assume categoricamente na localidade o papel de elemento condicionador da vulnerabilidade socioambiental. 
Envolve a dimensão da degradação ambiental, verificada, por exemplo, nas saídas de água contaminadas pelos efluentes do SAUMTVN para o seu universo como demonstram as condições impróprias de balneabilidade diagnosticadas em vários pontos das praias de Matinhos. Ao mesmo tempo se tipifica como importante elemento da vulnerabilidade social pela exposição dos moradores do SAUMTVN aos agentes patogênicos presentes nos efluentes, situação confirmada pela pesquisa pelos casos levantados nas áreas de Alta Vulnerabilidade Ambiental de doenças relacionadas ao contato com água das enchentes, inclusive com o registro de óbitos causados por leptospirose.

Estes dados, somados aos demais, atestam dois dos elementos clássicos que caracterizam a vulnerabilidade, quais sejam, a exposição ao risco e a (falta) capacidade de reação que tem como consequências as doenças, óbitos e perdas materiais, que por sua vez se associam aos altos níveis de privação, incapacidade de ativos, e nas moradias precárias, especialmente aquelas sem nenhum tipo de proteção contra inundações, as quais Chenesseau et al. (2007), consideram como as habitações mais vulneráveis. Os estratos de baixa renda das áreas de Alta Vulnerabilidade Ambiental estão entre os mais vulneráveis do ponto de vista social (78\% das famílias destas áreas tinham renda inferior a três S.M.M.). São essas famílias com condições econômicas precárias, ou com insuficiência de "ativos" (KAZTMANN e FILGUERA, 1999) que tem as maiores dificuldades para reagir perante a consumação dos riscos relacionados às inundações.

O terceiro elemento presente na vulnerabilidade é o grau ou a capacidade de adaptação. Classicamente se refere a medidas que visam à assimilação dos impactos adversos decorrentes dos eventos desastrosos e envolve providências individuais, de grupos e institucionais que possibilitem a convivência com as situações impactantes. A despeito do conceito de adaptação não se referir propriamente à redução dos impactos, muitos dos efeitos adversos resultantes das inundações e da degradação ambiental serão sensivelmente minimizados com a adoção de medidas mitigadoras.

Para o caso de comunidades, como a residente na área de abrangência do SAUMTVN, e também aquelas que vivem no seu universo sistêmico, especialmente no município de Matinhos, cujos riscos ambientais são conhecidos e a sua 
materialização é recorrente, urge ao nível comunitário o desenvolvimento de uma cultura de redução dos riscos definidas como um conjunto de práticas sociais de proteção social em relação aos riscos e que compreende atitudes, hábitos e comportamentos com vistas à redução dos riscos (UFSC, 2012). Essa ação deve ser combinada à adoção de medidas, estruturais e não estruturais (TUCCI 2012, p. 22 a 29) que tenham em perspectiva a redução das inundações, a eliminação das condicionantes da degradação ambiental, especialmente com a universalização dos serviços de coleta e tratamento dos esgotos e dos resíduos sólidos. Estas medidas devem se inserir em contexto da adoção de políticas públicas que visem o desenvolvimento sustentável da região, promovam o uso e a ocupação adequada dos espaços, incluindo a resolução dos problemas fundiários e das necessidades habitacionais da população local, especialmente a mais carente, a organização e participação popular e adote as providências necessárias para superar os preconceitos, a discriminação, a pobreza e as desigualdades que acentuam as vulnerabilidades.

\section{REFERÊNCIAS BIBLIOGRÁFICAS}

ALVES, H.P.F. Vulnerabilidade sociambiental na metrópole paulistana: uma análise sociodemográfica das situações de sobreposição espacial de problemas e riscos sociais e ambientais. In.: Revista Brasileira de Estudos Populacionais. São paulo, v. 23, n.1, p. 43-59. 2006.

BRUNET, $R$. et. al. Les mots de la géographie Dictionnaire critique. In.: Montpellier: GIP Reclus et La Documentation Française, 2. Ed. 520 p.

CHENESSEAU, M., ET AL. Trame verte et opération d'amélioration de l'habitat : deux manières d'aborder la prévention de l'inondation. In.: Les Études Ligériennes. Orleans, França, n. 14, p .57-60, 2007. Número especial do colóquio: "Hier, la crue de 1856. Aujourd'hui et demain, comment se préparer à un événement de cette ampleur ?". 132p.

DESCHAMPS, M.V., KLEINKE, M.P.U. Os fluxos migratórios e as mudanças socioespaciais na Ocupação Contínua Litorânea do Paraná. In.: Revista Paranaense de Desenvolvimento. Curitiba, n.99, p. 45-59. 2000.

EMBRAPA E IAPAR. Mapas de Solos do Paraná: Legenda Atualizada. In: Bhering,H. G. S. (ed). Rio de Janeiro: Embrapa Florestas: Embrapa Solos: IAPAR, 2008, 74p. 
ENGELS, F. Necessidade e acidente na história - Carta a H. Starkenburg. In: FERNANDES, F. (Org./Tradutor). Marx / Engels. São Paulo: Editora Ática, 1984. 2 Ed. p. $468-471$.

ESTEVES, C.J.O. Vulnerabilidade socioambiental na área de ocupação contínua do litoral do Paraná - Brasil. Curitiba, 2011. Tese de Doutorado (Programa de Pós Graduação em Geografia) Universidade Federal do Paraná. Disponível em <http://www.ipardes.pr.gov.br/biblioteca/docs/Tese_Claudio_2013.pdf>Acesso em 10/07/2014.

GODOY, A.M.G. Reestruturação produtiva r polarização do mercado de trabalho em Paranaguá-Pr. In.: Revista Paranaense de Desenvolvimento. Curitiba, n. 99, p. 5 $25,2000$.

KAZTMANN, R. e FILGUERA, C. Marco Conceptual sobre Activos, Vulnerabilidad y Estructura de Oportunidades. In.: CEPAL: Oficina de Montevideo, 1999. Disponível em < http://www.eclac.org/publicaciones/xml/6/10816/LC-R176.pdf>. Acesso em abril de 2010.

LEFF, E. Sobre a articulação das ciências na relação natureza-sociedade. In Epistemologia Ambiental. São Paulo, Ed. Cortez, 2002, 2.ed. p. 21-58.

MARANDOLA, E. J., HOGAN. D. J. As dimensões da vulnerabilidade. In.: São Paulo em Perspectiva. São Paulo: Fundação SEADE, v. 20, n. 1, p. 33-43, jan./mar. 2006

MENDONÇA, F. A. . Geografia socioambiental. In: ; KOZEL, S. (Orgs.). Elementos de Epistemologia da Geografia Contemporânea. Curitiba: Editora UFPR, 2002. p. $121-144$

SAU Sistema Ambiental Urbano: uma abordagem dos problemas socioambientais da cidade. In: Impactos Socioambientais Urbanos. Editora UFPR, 2004.

Riscos, vulnerabilidades e resiliência socioambientais urbanas: inovações na analise geográfica. In.: Revista da ANPEGE, v. 7, n. 1, número especial, p. 111-118, out. 2011.

MOURA, R. WERNECK, D.Z. Ocupação Contínua Litorânea do Paraná: uma leitura do espaço. In.: Revista Paranaense de Desenvolvimento. Curitiba, n.99, p. 61-82. 2000.

PARANÁ E MATINHOS. Plano Diretor Participativo e de Desenvolvimento Integrado - PDPDI - Matinhos, Paraná, Brasil: Diagnóstico Municipal: Sócioeconômico, Físico, Territorial - Caderno 1 de 2 (Proposta). Curitiba: 2006.

SACHS, I. Entering the anthropocene : 'Geonauts' or sorcerer's apprentices?, Social Science Information sur les sciences sociales (SAGE). v. 50, 2011, p. 462-471. 
Disponível em < http://dowbor.org/ar/11sachs_social_science_information-2011sachs-462-71.pdf> Acesso em 27/09/2014.

SAMPAIO, R. Ocupação das orlas das praias paranaenses pelo uso balneário. In: Desenvolvimento e Meio Ambiente, n. 13, p. 169-186, jan./jun. 2006. Curitiba: Editora da UFPR. 2006.

TUCCI, C. E. M. Gestão da drenagem urbana. Brasília, DF: CEPAL. Escritório no Brasil/IPEA, 2012. (Textos para Discussão CEPAL-IPEA, 48). 50p.

THOURET, J.C. e D'ERCOLE, R. Vulnérabilité aux risques naturelles en milieuurbain: effets, facteurs et réponses sociales. In.: Cahiers des Sciences Humaines, Paris, V.32, N. 2, pp. 407-422, 1996. ISSN: 0768-9829

UFSC. Gestão de riscos de desastres / texto Janaina Rocha Furtado. Florianópolis: CEPED UFSC, 2012. 14 p. : il. color. ; $21 \mathrm{~cm}$.

VANHONI, F. Fachada Atlântica Sul Do Brasil: Dinâmica e Tendências Climáticas Regionais no Contexto das Mudanças Globais. Curitiba, 2009. Dissertação de Mestrado (Programa de Pós-Graduação em Geografia). Universidade Federal do Paraná.

VEYRET, Y. e REGHEZZA, M. Vulnérabilité et risques L'approche récente de la vulnérabilité. In: Responsabilité \& Environnement, № 43, p. 9-14, julho.2006.Paris: Ed. Annales de Mines. Disponível em< http://www.annales.com/re/2006/re43/Veyret.pdf> Acesso em julho de 2014.

Declarações de moradores (Comunicação Pessoal)

Adriana Correa

Antônio Irineu Telles de Souza

Carolina Moraes

José Mendes

Júlio César Pauluk

Maria A. Duarte

Neiza Lopes Camargo

Rosilda Marinho Marques

Sônia Maria Tonon 